\title{
Principles that should guide mental health policies in low- and middle-income countries (LMICs): lessons from the Brazilian experiment
}

\section{Princípios que devem orientar as políticas de saúde mental nos países de baixa e média rendas (LMICs): lições do experimento brasileiro}

A public mental health policy must be sound, comprehensive, hierarchical, flexible, agile, and resolving. It also has to be accountable, feasible, just, and humanitarian. It must respond to the needs, priorities and rights of the population. Its success is a function of the efficacy of its interventions and of the "effectiveness of prevention strategies and early detection and treatment".${ }^{1} \mathrm{~A}$ list of services and expenditures provides no information on the delivery of care. The content, quality, and relevance of the care provided is more important: "It has been argued that valid measurement of the content of care provided to patients may be more crucial than attending to service style, setting or organization in understanding the links between service processes and outcomes" ${ }^{2}$ It is necessary to know what is offered, to whom, why, how, at which cost, and the ensuing benefits. Methods for the evaluation of the content of care have been available for some time, but there are no published studies of this kind in Brazil to date.

Over the past two decades, with the support and advice of the WHO Department of Mental Health and Substance Abuse, the Brazilian Ministry of Health's Coordination of Mental Health (CORSAM-MS), enacted a massive dehospitalization, shifting its limited budget onto psychosocial rehabilitation, alcohol and substance abuse programs, support of living, and leisure activities. Social, non-medical initiatives are obviously important, but should be jointly supported by the Ministries of Housing, Education, Labor, Justice, Culture, and Welfare. Directing the limited budget of the Ministry of Health to such activities and depriving the population of proper psychiatric care is contrary to the principle of social equity, and is unsound even from the economic standpoint. ${ }^{3}$ Our public health system and prevention programs must provide services to 190 million inhabitants, but very little goes, for instance, to the early diagnosis and effective treatment of anxiety and mood disorders.

There are two main fallacies in the current model: (1) that secondary prevention can be carried out by primary care services; and (2) that psychiatric beds in general hospitals and 24-hour Psychosocial Attention Centers (CAPS-III) would fill the gap left by the closure of $80 \%$ of the beds in psychiatric hospitals. The "World Mental Health Survey" showed that $76 \%$ to $85 \%$ of the patients with serious mental illnesses (e.g., anxiety, mood, impulse control, or substance use disorders) in low- and middle-income countries (LMICs) received no treatment for their conditions over 12 months. Like in many countries, Brazil's primary care physicians and general practitioners have insufficient psychiatric competence. Due to the lack of effective prevention, every year more than 6,000 people are admitted to hospitals due to bipolar depression or manic episodes in the State of São Paulo alone (with 40 million inhabitants, the most economically developed state in Brazil). WHO's recently published "Mental Health GAP Intervention Guide for mental, neurological and substance use disorders in nonspecialized health settings" (www.who.int/mental_health/mhgap) may help integrating mental health into primary care in LMICs. However, a change in the attitude and competence of the primary care teams towards psychiatric patients would require a major shift in the undergraduate curricula of Medical Schools, in order to include psychiatry as a core discipline and to provide intensive clinical training in psychiatry. Likewise, nurses, psychologists, and other mental health professionals should receive up-to-date information and training in intervention techniques with sound scientific bases and proven efficacy. This would take years to implement. Until then, the specialized psychiatric outpatient clinic shall remain the most competent provider of effective prevention and care. However, most local administrations are not able to set up outpatient clinics because the Unified Health System (SUS, in the Brazilian acronym) reimburses an outpatient appointment with less than US\$ 6 .

It is now widely acknowledged that hospital beds cannot be closed before commensurate alternative services are established. A hospital - a medical inpatient facility for complex interventions - can be set as a non-restrictive institution, and may have a lower cost than an equivalent amount of beds in a psychiatric unit of a general hospital (PU-GH). A PU-GH is an important resource, and more of them are needed in this country. However, it must not be confused with psychiatric beds in a GH. More than 400 psychiatric beds are located in hospitals with four or less beds each, which are unable to afford to have specialized mental health teams. For some patients and regions, a modern psychiatric hospital may be the most appropriate and viable equipment for acute psychiatric care. In fact, some old asylum grounds are been 
redeveloped to include modern psychiatric hospitals in the United States (e.g., Saint Elizabeths, in Washington, D.C.) and France (e.g., Sainte Anne, in Paris). Unfortunately, since the 1980s, the Brazilian governments enacted a radical dehospitalization policy, closing nearly 85,000 psychiatric beds, whilst opening less than 850 beds in GH and 230 beds in 24-hour CAPS-III.* In 2010, the CORSAM-MS listed 35,426 beds in psychiatric hospitals, $50 \%$ of which are to be closed when their long-term occupants are discharged, moved, or die. The list includes 3,062 former longterm inpatients housed in "residential therapeutic services"; 2,568 psychiatric beds in GH; and less than 250 beds in 46 CAPS-III. (http://portal.saude.gov.br/portal/arquivos/pdf/smdados.pdf).

If effective psychiatric prevention is to have a higher priority in this country, a major reform of the current model is required. The "Guidelines for a Comprehensive Mental Health Care Network", published by the Brazilian Psychiatric Association in 2006 and backed by the Federal Medical Council in 2010, suggests some alternatives. The new "Psychiatric Specialty
Outpatient Clinic" ("AME-Psiquiatria”), set up in a working class neighborhood (Vila Maria) in the city of São Paulo by the State of São Paulo Government through the "Sociedade Paulista para o Desenvolvimento da Medicina" (SPDM - UNIFESP), with technical support from the departments of psychiatry of four medical schools, is a new development. With tailored programs for child and adolescent, alcohol and substance abuse, mood and anxiety, acute psychoses, and geriatric psychiatry, ${ }^{5}$ the Clinic is testing the hypothesis that evidence-based secondary prevention can provide cost-effective, high-standard care in a public mental health services network. After all, among the rights outlined in the Brazilian Mental Health Law 10,216, Article 2 states that "patients are entitled to the best available treatment of the health system for their needs". For most people, this means effective psychiatric care.

Valentim Gentil Medical School, Universidade de São Paulo (USP), São Paulo, SP, Brazil

\section{Disclosures}

\begin{tabular}{|c|c|c|c|c|c|c|c|}
\hline $\begin{array}{l}\text { Writing group } \\
\text { member }\end{array}$ & Employment & $\begin{array}{l}\text { Research } \\
\text { grant }^{1}\end{array}$ & $\begin{array}{l}\text { Other research } \\
\text { grant or medical } \\
\text { continuous } \\
\text { education }^{2}\end{array}$ & Speaker's honoraria & $\begin{array}{l}\text { Ownership } \\
\text { interest }\end{array}$ & $\begin{array}{l}\text { Consultant/ } \\
\text { Advisory } \\
\text { board }\end{array}$ & Other $^{3}$ \\
\hline Valentim Gentil & USP & Novartis* & - & $\begin{array}{c}\text { Janssen }^{*} \\
\text { AstraZeneca* }\end{array}$ & - & Servier* & - \\
\hline $\begin{array}{l}{ }^{*} \text { Modest } \\
{ }^{* *} \text { Significant } \\
{ }^{* * *} \text { Significant: A } \\
\text { author. } \\
\text { Note: USP = Uni } \\
\text { Fundação de An } \\
\text { For more inform }\end{array}$ & $\begin{array}{l}\text { unts given to } \\
\text { sidade de São } \\
\text { ro à Pesquisa } \\
\text { n, see Instruct }\end{array}$ & $\begin{array}{l}\text { author's ins } \\
\text { Estado de N } \\
\text { for Authors }\end{array}$ & $\begin{array}{l}\text { on or to a colleag } \\
\text { Gerais. }\end{array}$ & research in which th & uthor has & pation, not & ty to th \\
\hline
\end{tabular}

Referências

1. Shah A, Jenkins R. Mental health economic studies from developing countries reviewed in the context of those from developed countries. Acta Psychiatric Scand. 2000;101(2):87-103.

2. Lloyd-Evans B, Johnson S, Slade M. Assessing the content of mental health services: a review of measures. Soc Psychiatry Psychiatr Epidemiol. 2007;42(8):673-82.

3. Andrews G, Issakidis C, Sanderson K, Corry J, Lapsley H. Utilizing survey data to inform public policy: comparison of the cost-effectiveness of tragtment of ten mental disorders. Br J Psychiatry. 2004;184(6):526-33.

4. Demyttenaere K, Bruffaerts R, Posada-Villa J, Gasquet I, Kovess V, Lepine JP, Angermeyer MC, Bernert S, de Girolamo G, Morosini P, Polidori G, Kikkawa T, Kawakami N, Ono Y, Takeshima T, Uda H, Karam EG,
Fayyad JA, Karam AN, Mneimneh ZN, Medina-Mora ME, Borges G, Lara C, de Graaf R, Ormel J, Gureje O, Shen Y, Huang Y, Zhang M, Alonso J, Haro JM, Vilagut G, Bromet EJ, Gluzman S, Webb C, Kessler RC, Merikangas KR, Anthony JC, Von Korff MR, Wang PS, Brugha TS, Aguilar-Gaxiola S, Lee S, Heeringa S, Pennell BE, Zaslavsky AM, Ustun TB, Chatterji S; WHO World Mental Health Survey Consortium. WHO World Mental Health Survey Consortium. Prevalence, severity, and unmet need for treatment of mental disorders in the World Health Organization World Mental Health Surveys. JAMA. 2004;291(21):2581-90.

5. Araújo-Filho GM. Novo modelo pode fortalecer rede de atenção integral à saúde mental. Psiquiatria Hoje - Debates. 2010;4:9-11. 